Miloš Nikolić ${ }^{1}$

Tamara Vesić ${ }^{2}$

Maja Cogoljević3

Faculty of Business Economy and Entrepreneurship

Belgrade, Serbia
SCIENTIFIC REVIEW ARTICLE doi:10.5937/ekonomika1901047N

Received January, 07, 2019

Accepted: March, 11, 2019

\title{
THE INFLUENCE OF THE STRATEGIC DEVELOPMENT OF MODERN TECHNOLOGIES ON THE FACTORS OF COMPETITIVENESS AND ECONOMIC GROWTH
}

\begin{abstract}
In today's time of modern business, where the most important environment or competition, which is increasingly specific to the globalization of markets and economic regulation, we can say it is unsuccessful without the use of digital technologies and the Internet. Powerful competition can bring significant benefits to consumers, taking into account that manufacturers are superior in terms of product quality, prices, service delivery, warranty period, deferred payment and various other bonuses to attract as many customers as possible to their product or service. The subject of research is the influence of the Internet and digital technology on the development of competitiveness. The key competitiveness factors of the companies on the market are current competitors, potential competitors, substitutes, customers and suppliers. These factors actually represent Potter's model of five forces, and they will be further elaborated below, each individually.
\end{abstract}

Key words: competitivness, modern technologies, economic growth, Potter's model

JEL classification: $O 1,021$

\section{УТИЦАЈ СТРАТЕГИЈСКОГ РАЗВОЈА МОДЕРНИХ ТЕХНОЛОГИЈА НА ФАКТОРЕ КОНКУРЕНТНОСТИ И ЕКОНОМСКИ РАСТ}

\begin{abstract}
Апстракт
У данашьем времену савременог пословања, где је веома битно окружење, односно конкуренција, које је у свету повећане глобализачије тржишта и економске регулације врло специфично, можемо рећи да је пословаье безуспешно без употребе дигиталних технологија и интернета. Снажна конкурениија, може донети значајне користи потрошачима, узимајући у обзир да се произвођачи надмећу у смислу квалитета производа, иена, реализоваюу услуга, гарантног рока, одложеног плаћања и разних других бонуса како би привукли што више клијената на свој производ или услугу. Предмет истраживаға рада јесте
\end{abstract}

\footnotetext{
${ }^{1}$ milos.nikolic@vspep.edu.rs.

${ }^{2}$ tamara.vesic@vspep.edu.rs.

${ }^{3}$ maja.cogolljevic@vspep.edu.rs.
} 
утицај интернета и дигиталних технологија на развој конкурентности. Кључне факторе конкурентности привредних субјекта на трзишту представљају актуелни конкуренти, потенцијални конкуренти, супститути, купци и добављачи. Ови фактори заправо представљају Потреров модел пет сила, и они цее бити детаљније обрађени у наставку, свака понаособ.

Кључне речи: конкурентност, модерне тецхнологије, економски развој, Потеров модел

\section{Introduction}

In today's time of modern business, where the most important environment or competition, which is increasingly specific to the globalization of markets and economic regulation, we can say it is unsuccessful without the use of digital technologies and the Internet. Powerful competition can bring significant benefits to consumers, taking into account that manufacturers are superior in terms of product quality, prices, service delivery, warranty period, deferred payment and various other bonuses to attract as many customers as possible to their product or service (Urrutia, 2010, p.10). However, the networking of enterprises and public administration and the development of the Internet contributed to great changes in the functioning of business systems. In this way, simple and fast communication is enabled, the transmission of a large amount of data in, it can be said, one time at a great distance, Internet payment, the creation of new virtual organizations and other benefits. On the contrary, what may not be the best part of this type of business, is that there was increased pressure among competitors. This pressure is most likely created by the gap between the most successful companies, and those less successful, who are struggling to survive on the market. Because of this, the research has shown that efficient companies, in static business, can not withstand the pressure without innovations that are crucial for the survival of enterprises in the capitalist economy. Companies face the ever-increasing need for digital transition, and it is necessary to adapt to new changes in a very quick and efficient way (Prepletaný, 2013 , p.54). Only those companies that adapt very quickly to new conditions can survive on the market. The speed, scope and impact on the system have led to the fourth industrial revolution that further enhances the role of information and communication technologies in companies. The subject of research is the influence of the Internet and digital technology on the development of competitiveness (Protic \& Lazarevic, 2015, p. 87). The key competitiveness factors of the companies on the market are current competitors, potential competitors, substitutes, customers and suppliers. These factors actually represent Potter's model of five forces, and they will be further elaborated below, each individually. Internet and digital technologies, by creating new ways to add value and shifting the power of five competing forces, have changed the competitive climate in numerous economic activities (Kalac, Masovic, \& Ahmetovic, 2017, p. 36). These changes often require the modification of generic strategies, which sometimes lead to new combined strategies. 


\section{Competition on the internet}

We can say that there are two facts that relate to key Internet basic objects. The first is that the Internet is based on telecommunications networks and there are a number of networks - the so-called basic Internet - controlled by an extremely limited number of companies. Second, it's someone who needs to administer and manage the Internet system. This "someone" plays a key role in the development of the Internet market.Competition is a game - a game that provides end-to-end supplies and functions of demand for a particular good or service interact in an efficient way (Krstic, Gavric \& Skorup, 2018, p. 187). This game requires a playground and fair rules for the game. We can call the playing field "Market" or, more precisely, "relevant market". Competition rules, also called the principles of antitrust, ensure a fair development of the game. These rules are basically forbidden by two things: agreements and / or practices between competition that distorts competition (what we call a secret agreement) and the abuse of the market of monopolists or groups of oligopolists enjoying the dominant position of those markets (Evans, 2015, p. 24). The purpose of the ban to ensure the success or failure of the Player depends solely on its own ability to compete. Competition rules are not applied abstractly. They are always applied in markets that have very precise boundaries. We need to be clear about who you are competing with, for which product or service and within which geographic areas. Now, the Internet is not a threat or a competing advantage. It's not even a market. We can consider the Internet as a system of communication on a global network, so-called World Wide Web (Stojanovic \& Kostic, 2017, p.9). This system can be used in many ways and for various purposes by different people. From an economic perspective, we could see it as a kind of commodity that allows companies to compete - that is, to offer, sell, buy and (sometimes) distribute goods and services - in a different way. These are concepts like e-commerce or e-commerce (Balto, 2000, p. 280).

\section{Role and challenges of competition policy in the ICT sector}

When it comes to the relevant market, it can be said that this is the most important element and the starting point for acting in the competition protection segment. Proper assessment of market share and indirect market power of businesses depends on the exact definition In the era of expansion of the ICT sector, the global view of competition policy is a change. The situation is similar in Serbia. Under the influence of high concentration and interlacing services from individual markets, there are three basic directions that competition policy applies to modern information and changes in communication technology (ICT). The directions of change are (Shannon \& Weaver, 2016, p. 78):

1. Changing the angle of view and assessment of the relevant market;

2. Balancing between good and bad parties related to engaging in the sphere of research and development ( $R$ \& D) and,

3. Careful relationship to patents and licenses, as a basis for the protection of intellectual property, as well as obstacles to entering the new market.

Taking into account that the market's borders are too broad, it may seem that companies are significantly lower market forces, and therefore it can be overlooked that companies have higher market power, but in reality this is not the case. The relevant market has two components, 
one for products, and the other in the territory where these products are offered, therefore there is a relevant product market and the relevant geographic market (Turban, 1993, p.26 ). Therefore, the relevant product market is a set of goods or services that consumers and other users consider substitutable in the sense of the common purpose, characteristics and price, while the relevant geographic market of the territory in which the participants participate in the offer or demand and where there are the same or similar conditions of competition, which are significantly different from the conditions of competition in neighboring territories (Lashkova, et al., 2018, p. 37). As such, the phenomenon of the relevant market is narrower than the phenomenon of the general concept of the market, which includes the exchange of goods and services across the territory, regardless of the conditions of competition and the existence of product substitutability.

\section{Technology opens new data source}

All technological innovations, platforms and applications represent a huge potential form of access to previously untapped data sources. Data can now be collected, e.g. at the point of sale, and analyze to gain a more complete view of the customer, on the one hand and on the other hand, to improve and enrich the overall user experience. Moreover, customers are no longer just "customers". They are creators of content, merchants and advertisers. They blog and talk about products with their friends, colleagues, followers, while expanding on-line sales. They check and contribute to the product review websites, as well as for the retailing of their own websites and social media sites, expressing their liking, not appeasing and recommendations. They advocate quality purchased products and services with one hand while belittling brands and companies that do not fulfill their promises. Mobile digital technologies enable this and much more anywhere and anytime.

The ability to instantly publish experiences on social media sites and allow others to comment on posts change consumer behavior in relation to information, collaboration, interaction, entertainment and maintaining overall awareness. It also changes the way consumers perceive and react to ads. Stankić et all (2018) identifies earned media as the most reliable form of advertising for clients. If retailers can take advantage of this trend of open and unwieldy downloading of communications by putting them on the Internet, this will inevitably lead to a better position of retailers to formulate up-to-date decisions in the areas of merchandising and inventory planning, product and service prices, marketing (online and offline) and personal targeting. By maintaining integrated communications on both physical and virtual channels, vendors can have access to digital channels to enhance service in the store.

This is the beginning of the introduction of large data and analytics in the retail industry. It is known that data is running business and large data analysis can help marketers to deepen customer insight and bid adjustment, both on-line, and on the basis of a previous overview of consumer behavior, transactions and interactions while reducing marketing costs, increasing messages optimizing and maximizing overall marketing performance (Berisha-Shaqiri, 2014, 22). On top of this, large data from digital devices means that traders can more closely monitor customer behavior in real time. This requires managing customer relationships and targeted marketing unprecedentedly. Large-scale mining, retailers have a stronger platform for better management of existing new relationships. 


\section{Extraordinary limitations of the use (or misuse of) internet for operations}

The Internet can be a great system for conducting commercial transactions, buying and selling many things. However, there are limits to what can be sold or purchased on the market, regardless of its "virtual" or traditional nature. There are other limitations on how you can trade with good or service. Certainly, certain issues such as the privacy of our data on the Internet, consumers' rights and obligations (consumer protection) over the Internet, tax on electronic commerce transactions, dispute resolution between parties trading on the Internet and the prevention of cybercrime should be posed (Kroenke \& Hatch, 1994, p. 58). Then, it is possible to discuss the legal framework currently under construction in the EU for the purpose of conducting electronic business trade. This framework would be based on the recently adopted Electronic Commerce Directive and the envisaged directives on electronic money, property rights over Internet protection or data. All these regulations would finally establish the limits within which competition on the Internet markets will develop. It is important to understand that neither the European Union, nor the United States nor any other economic area in the world can unilaterally impose a framework without the prior consensus of other areas (Čeganjac, Kostadinović \& Đuričić, 2012, p. 98). Firstly, because the Internet is what it is, it is global in nature and unlimitedly open to all users in the world. Secondly, because this nature leads to extra-territorial effects - i.e. decisions adopted far from our borders that have direct implications for our business and consumers who demand it by international negotiations (Lunenburg, 2012, p. 7). Otherwise, there is a real risk that is different, contradictory solutions are being implemented - or attempted to apply - in different regions of the world. Today, it would be highlighted as a more difficult issue for such negotiation, the aspect of using private data for commercial purposes on the Internet, to which the EU would have a more restrictive approach than the US, or an approach to the enforcement of corporate tax rules outside the EU, but acting on the inside market via the Internet.

\section{Completed competition on the internet}

For many companies, the Internet represents a business opportunity, the ability to implement investment projects with high expected return rates, improving competitive advantage or corporate diversification strategies. For many other companies - for some business sectors in general, in some cases - the Internet can pose a serious threat, as the functions they perform will disappear with the development of e-commerce. This would be the case with many intermediary functions (wholesalers, retailers) for which direct Internet competition is possible. The Internet not only jeopardizes mediation functions. This is also a challenge for territorial protection agreements, i.e. for a seller who gets full exclusivity for the commercialization of some goods in a particular territory. The Internet makes it very easy to know at what prices these goods are offered in neighboring or distant territories and provide resources for their acquisition from different resellers. It is not unthinkable that these characteristics can lead to many traditional traders and a category of companies that oppose new forms of competition over the Internet. Moreover, for the full exploitation of Internet business opportunities, we are witnessing the concentration of economic power - both in the 
form of mergers and in the form of strategic agreements between companies - which might be necessary to justify the so-called new economy, but this could mean that the market structures in This new economy will be controlled by a limited number of players on a global scale. Consider, for example, the planned mergers between America on Line and Time Varner or Vivendi / Canal Plus and Seagram. Finally, from a social standpoint, the first requirement for participation in a new economy based on the ubiquitous use of the Internet and digital technologies is that it has access to the Internet and those technologies.

It is now clear that even in industrialized countries, a large part of the population will remain outside the Internet. This could mean a social breakdown that could have negative consequences for the proper functioning of the economic system. These consequences would also appear at the international level in relation to relations with developing countries (Nikolić, Vesić \& Stošić-Mihajlović, Lj, 2017, p. 23).

Image 1: Five Powers of Internet Affiliation:

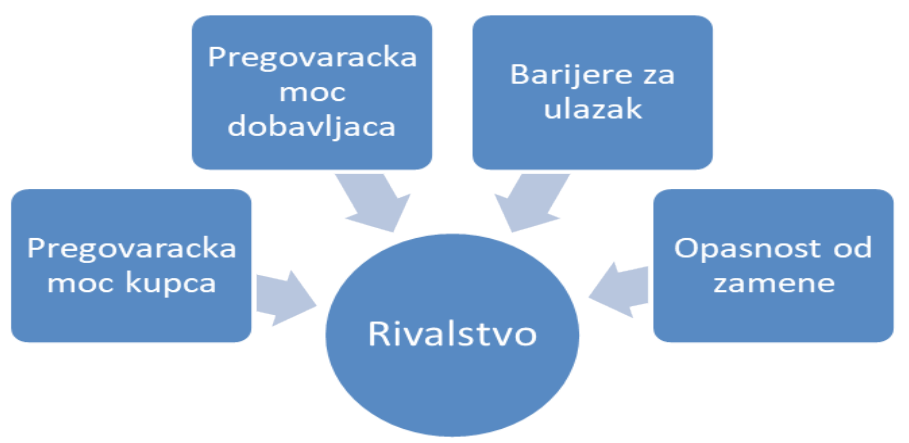

Source: Evans, 2015, p. 1.

\section{Entry of new competitors}

There is no doubt that digital business is changing the nature of competition. Today you do not have to worry only about traditional competitors in the industry, but about new participants outside your industry, equipped with new business models based on digital form and values (Momčilović et all, 2017, p.150). Often these are technological giants and startups that have conceived and built a new business model from the foundation, based on the new ecosystem of the digital business platform. They use well-known social, mobile, analytical and cloud technologies, but they often add personas and context, intelligent automation, Internet stuff and cyber security to further enhance the value of their platform (Živadinović, Medić, Skorup, 2016, p. 36). In fact, tomorrow's leader may not be someone you know. Competition in industry is often regarded as a constant struggle between the same set of carriers, but in reality, things are far more dynamic and transient (Poliščuk, 2007, p. 97). As an example, while $89 \%$ of Fortune 500 went out of business between 1955 and 2014, in recent years, according to R "Rai" Wang of Constellation Research, 52\% was merged, acquired, bankrupt, or fell from the list only 2000. year. Why are new participants moving easily? Digital business changes rules by reducing traditional barriers to entry. A business model based on digitization requires far less capital and can bring large economies of scale (Vesić \& Radić, 2018, p. 60). 


\section{Threats to substitutions}

The danger of a substitute has to do with the threat of replacement products or services. Since the Internet allows for the same jobs to be enabled and done in new ways, the risk of substitution increases. As far as digital business is concerned, this can come from pure digital replacements or hybrid digital / physical replacements. Taxi services, such as Uber and EasyTaxi, for example, provide a hybrid model via a digital application for consumers and taxi drivers, along with a physical taxis. Digital services wrapped around the physical product are yet another example and can move from one extremity such as the industrial Internet to others, such as home automation technologies or personal fitness products.

In addition, the long-term flow of revenue from digital services can be worth much more than a one-time sale of a physical product. The risk of substitution is high in many industries, because the cost of switching is low and the willingness of customers to replace it is high. In the case of taxi services, users can easily switch from traditional models to a new model by simply installing an application on their smartphone (Papić, Stanojević \& Mandić, 2017, p. 196). The tendency to switch from a traditional model is high because of customer waiting time for taxis, lack of visibility at the taxi site, and so on.

\section{Bargaining power of customers}

Perhaps it is the strongest of the five forces that affect the competition in the industry negotiating power of customers, because the biggest driver of digital business comes from the needs and expectations of consumers and customers themselves. Due to the fact that consumers provide more information when making purchasing decisions and reducing the cost of switching, it can be said that Internet and wireless technologies can increase the negotiating power of the buyer. This bargaining power represents a new set of expectations for digital customer experience and requires sustained corporate innovation in all business models, processes, operations, products and services (Anđelić, Rastić \& Ilić, 2017, p. 149). Customers and consumers today have gained much more bargaining power due to instant access to information, social media insights, including access to reviews and feedback, low cost of switching over digital channels, price sensitivity, access to substitute products and services with greater ease of use and as well as increased competitiveness of the industry as a result of other forces. The Internet increases the power of the buyer or consumers through the Internet because, first and foremost, a large number of information is relevant to the Internet, and then, the costs that the user pays for this way of the house are low because of the Internet. Because of this, companies that intend to seriously deal with this mode of selling must more closely listen to the needs of the customer as well as to respond efficiently and relatively quickly to their demands.

\section{Bargaining Power of Suppliers}

To what extent will the Internet be an advantage or an aggravating circumstance, it can depend on the position of the supplier along the value chain, as is the case with the buyer's power. Suppliers can accelerate or slow down the adoption of a business model based on digitization based on the way they affect their situation. Those who deal with digital models themselves, such as using APIs to simplify the ability to form new partnerships and manage existing ones, can help accelerate your model. The effect of the Internet on the power of the supplier depends on the nature of the competition in a specific activity. Those who are traditional 
model suppliers and who are asking or still determine their new role in the digital equivalent can use their bargaining power to slow down or challenge the validity or legality of the new model (Vesić \& Petronijević, 2018, p.151). Good examples are legal and business issues that emerge in the economy of sharing digital data (eg sharing, sharing rooms, etc.) where suppliers and other members work to ensure that the business model and process innovations still respect the established rules, regulations, privacy and security (Anđelic \& Vesić, 2017, p. 18). This is a positive and necessary development, because, together with the negotiating power of the customers, it can help to keep the new models "fair" in terms of their functioning.

\section{Rivalry among existing competitors}

Finally, existing competitors look at the digital business, trying to understand the disruptions that arise and prepare their answer. The answers can range from defensive to offensive measures, and even attack on the first movement (Stošić-Mihajlović \& Nikolić, 2017 , p. 82). Only those competitors who can use digital technologies and the Internet to create a recognizable image, who have recently offered products or services, will be able to capture much of the profits with the help of new technology. This rivalry among competitors is always in the game, but in recent years digital business has added fuel to the fire, just as e-commerce has been going on for many years. Rivalry is heated because inbound and outbound barriers are reduced due to comparative low-cost digital business models, and in many cases new entrants do not even have to have physical assets or infrastructure.

In particular, the "platform" model sees significant success on the market by simply connecting stakeholders and applying a set of peripheral services to enhance user experience. In this way, platform operators move to the forefront of service delivery and approach the client without having assets or employees working in the industry (Anđelić, Nikolić \& Vesić, 2017, p. 90). According to an article in The Guardian, "Today, any service provider, and even content provider, is risking to become a host of platform operators, which, uniting all these peripherals and simplifying their use, suddenly shifts from the periphery to the Center." In all, while preparing different digital business initiatives, a five-force framework can be a useful way of thinking about the different winds and winds that act on the imaginary model and how different ingredients can react. In combination with a common value chain analysis, it can help inform about your strategy and provide some useful insights into what you can find in the way.

\section{Conclusions}

Communication is a game that requires fair rules and games in a field called the market. In this game, two things are forbidden, agreements between competitors and the abuse of the market of mopnopolost and ologopolists who enjoy the dominant position on the market to ensure success or failure. The relevant market is a set of goods and services that consumers and other users consider substitutable in terms of common purpose, characteristics and prices. We can observe the Internet with a system of communication on the World Wide Web that is used by various people for various purposes. Changing the viewing angle, balancing between good and bad parties related to the elimination of the sphere of research and development, and attentive attitude towards patents and licenses are the basic directions to which the competition policy relates and the changing of technology communications. There are limits to what can be bought or sold on the market, regardless of its virtual or traditional nature. The Internet is global 
by nature and unlimited and open to all, and therefore neither the EU nor the US has been any other economic area that can not unilaterally impose a framework without a prior consensus.

Digital business hampers the five forces of competition in the industry. These forces are competitiveness, the danger of a substitute, the negotiating power of the buyer, the negotiating power of the supplier and barriers to entry. Today we do not have to worry about traditional competitors in India, but about equipped new business models based on digital form and values. As the dangers of substitution are concerned, this danger is high in many industries, as the cost of obtaining is low and the inclination of customers to replace is high. Perhaps the strongest of the five forces is the negotiating power of the buyer, because the biggest driver of digitized business comes from the needs and the aching of the customers themselves. Also, in the last section, we also asked the questions to be asked when choosing a business plan and revitalization.

\section{References}

Anđelic, S., \& Vesić, T. (2017). The importance of financial analysis for business decision making. In V. Ristanović (Ed.), Employment, Education and Entrepreneurship EEE2017 (pp.9-25). Belgrade: Faculty of Business Economy and Entrepreneursip.

Anđelić, S., Nikolić, M., Vesić, T. (2017). Strategic adjustment of the company changes, doi:10.5937/ekonomika1702087A, Ekonomika, 63(2), 87-95.

Anđelić, S., Rastić, A., \& Ilić, D. (2017). Analysis od Trade Condition in Ras Region, International Review, 2(2), 143-148.

Balto, D. (2000). Emerging Antitrust Issues in Electronic Commerce. Journal of Public Policy \& Marketing, 19(2), 277-286.

Baračkai, Z. (1987). Odlučivanje o poslovnim strategijama. Sarajevo: Svjetlost.

Berisha-Shaqiri, A. (2014). Management Information System and Decision-Making, Academic Journal of Interdisciplinary Studies, 3(2),19-23.

Čeganjac, Z. Kostadinović, J., \& Đuričić, M. (2012). Značaj menadžera u oblasti informacionih sistema. In M. Bogavac (Ed.), Menadžment 2012 (pp. 96-99). Mladenovac: Faculty of Business and Industrial Management ICIM plus.

Evans, N. (2015). How digital business disrupts the five forces of industry competition, downloaded on $27^{\text {th }}$ of December 2018. from site https://www.cio.com/ article/2976572/emerging-technology/digital-disruption-from-the-perspective-ofporters-five-forces-framework.html .

Kalač B., Mašović I., \& Ahmetović A. (2017). Izbor strateskih opcija u uspostavljanju ravzoja preduzetnickih organizacija. Novi Pazar, Srbija: Internacionalni Univerzitet Novi Pazar.

Kroenke, D., Hatch, R. (1994). Management Information Systems, Mitchell McGraw-Hill.

Krstić, M., Gavrić, G., \& Skorup, A. (2018). Strategijski menadzment. Beograd, Srbija: Visoka škola za poslovnu eknomiju i preduzetništvo.

Lashkova, Y., Berdibayeva, S., Beissenova, Z., Mun, M., Faizullina, A., Serimbetov, B., \& Gizatullina, A. (2018). The phenomenon of disappearances in the process of supervision in a permanent professional multimodal supervision group, Psychiatr Psychol Klin,18 (1), 35-40. 
Lunenburg, F. (2012). Organizational Structure: Mintzberg's Framework, Intentational Journal of scholarly, academics, intellectual diversity, 14(1), 1-9.

Momčilović, O., Obućinski, M., Cvetić, T., Vesić, T., \& Vujičić, S. (2017). Application of structural equation modeling in function of sustainable success of business entities. In S. Arsovski (Ed.), Quality of Life (pp. 145-151). Kragujevac: Center for Quality, Faculty of Engineering, University of Kragujevac.

Nikolić, M., Vesić, T., \& Stošić-Mihajlović, Lj. (2017). Upravljanje znanjem, informacijama i organizacionim promenama, Trendovi u poslovanju, 10(2), 19-28.

Papić M., Stanojević Lj., \& Mandić B. (2017). Primer razvoja informacionog podsistema za naplatu porudžbina u restoranu. In A. Veljović (Ed.), Informacione tenologije, obrazovanje i preduzetništvo - ITOP17 (pp. 193-200). Kragujevac: Faculty of Techinical Science University of Kragujevac.

Poliščuk, J. (2007). Projektovanje informacionih sistema. Podgorica, Crna Gora: Elektrotenički fakultet.

Prepletaný, D. (2013). The Impact of Digital Technologies on Innovations in Retail Business Models. Aalborg, Denmark: Aalborg University.

Protic, D., \& Lazarevic, N. (2015). Politika konkurencije u Srbiji-U čemu je problem? Beograd, Srbija: Centar za evropske politike.

Shannon, C., \& Weaver, W. (2016). A Dictionary of Media and Communication, Oxford University Press.

Stankić, R., Stojković, D., \& Soldić-Aleksić, J. (2018). Analiza potreba zaposlovnim informatičarima na tržištu radne snage Srbije, Anali Ekonomskog fakulteta u Subotici, 54 (39), 235-247.

Stojanovic, B., \& Kostic, M. (2017). Information and communication technologies product market and protection of competition in the Republic of Serbia. Ekonomika, 64(1), 1-12.

Stošić-Mihajlović, Lj., \& Nikolić, M. (2017), Social entrepreneurship supported by creative economy, doi:10.5937/ekonomika1704075S, Ekonomika, 63(4), 75-88.

Turban, E. (1993). Decision support and expert system. Macmillan Publishing Company, Third Edition.

Urrutia, B. (2010). Internet and its effects on competition. Paper delivered to the Universidad Internacional Menendez Pelayo (UIMP) Workshop. Barcelona, Spain.

Vesić, T., \& Petronijević, J. (2018). Trends in profitability of banks in Serbia through rational analysis. In D. Cogolojević (Ed.), Finance and insurance sector industry (138-155). Belgrade:Faculty of Business Economy and Entrepreneurship.

Vesić, T., \& Radić, N. (2018). Foreign banks - drivers of efficient development or yet another problem?, DOI: 10.15308/finiz-2018-56-62. In M. Stanišić (Ed.), The role of financial and non-financial reporting in responsible business operation - FINIZ 2018 (p. 56-62). Belgrade: Singidunum University.

Živadinović, J., Medić, Z., Skorup, A. (2016). Poslovna informatika. Belgrade: Faculty of Business Economy and Entrepreneursip. 